Military Technical College Kobry El-Kobbah, Cairo, Egypt

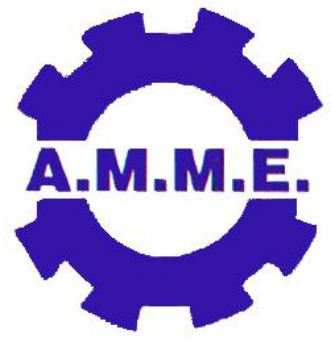

$14^{\text {th }}$ International Conference on Applied Mechanics and Mechanical Engineering.

\title{
Packaged Software Selection within Iranian Manufacturing SMEs: A Case Study
}

By
Norzima Binti Zulkifli *
Morteza Ghobakhloo *
Faieza Abdul Aziz *

\begin{abstract}
:
Nowadays, worldwide competition and need for possessing competitive advantage have forced Iranian small and medium sized enterprises (SMEs) to employ information technology (IT) to take advantage of their benefits. Due to SMEs' special characteristics generally referred to as resource poverty, these businesses are more inclined to purchase packaged software to meet their organizational needs for advanced computational technologies. However, the evaluation and selection of appropriate packaged software which satisfactorily meet these requirements is a complicated software engineering process and the selection of wrong packaged software can dramatically impose negative impacts over business processes and profitability. Using a questionnaire-based survey to collect data from the managers of manufacturing SMEs, IT experts, vendors, producers of packaged software and software engineers in Iran, as well as through applying the multiple criteria decision making (MCDM) method, TOPSIS, this paper aims to answer the question which domestically provided software package is the fittest with the needs of Iranian manufacturing SMEs. The methodology and findings offer valuable insights to decision makers to select the most appropriate packaged software to fit with business process.
\end{abstract}

\section{Keywords:}

Iran, packaged software, small and medium-sized enterprises, TOPSIS 
* Department of Mechanical and Manufacturing Engineering, Universiti Putra Malaysia, 43400 Serdang, Selangor, Malaysia 


\section{Introduction:}

The contemporary globalized market dominated by information revolution has metamorphosed result that companies need to intensify investment in computerprocessing and data preparation appliance to sustain their competitive positions [1]. On account of these technological advancements, the implementation and application of Information Technology (IT) has been increased to improve overall business efficiency through reducing total costs, adding value to products and services, maximizing return on investment and providing better services to customers, [2] in particular in SMEs [3, 4, 5, 6]. Like large organizations, SMEs are incrementally employing IT to made preparations for possessing sustainable competitive position in highly dynamic economy [7]. Notwithstanding IT has been considerably integrated and applied to business, numerous surveys conducted through the SMEs have shown a member of unsuccessful IT adoptions $[8,9,10]$. As a result, in order to address this problematic situation, a variety of solutions have been proposed which includes the use of packaged software [11]. There is rich buddy of literature suggesting that organizations including SMEs are increasingly shifting from using general IT application and developing new software to standardized, packaged software which is designed and developed for specified applications [11, 12]. Packaged software is a form of information technology application in the market and is provided by vendors, distributors/ representatives and stores [12]. These types of IT solutions have been largely popularized since Enterprise Resource Planning (ERP) was introduced in 1990s [11]. Packaged software can cover wide range of organizational processes and activities such as word processing, inventory control, accounting, production planning and control, simulation and Customer relationship management (CRM) [12, 13, 14, 15, 16].

In the context of SMEs, process of selecting and purchasing packaged software appears to be different due to specific characteristics of these businesses [1]. It has been exhaustively substantiated that SMEs have specific uniqueness and characteristics that differentiate them from large organizations. A number of factors such as intrinsic behaviors and characteristics of the industrialist or owner/manager may bring about the se dissimilarities. It has long been acknowledged that the management methods and functions of SMEs are dissimilar to large organizations [17]. SMEs mainly have simple and highly centralized structures with the chief executive officers (CEOs) in which, in most cases, owner and chief manager are one and same person [17]. A number of studies have revealed that in SMEs, the role of CEOs (top management or owner/manager) is central to enterprise since their decision influence all firms' activities, both in current and in future $[18,19]$. This also refers to IT adoption decision from planning stage to implementation, maintaining and system upgrade stages [3].

Consequently, with regard to SMEs' unique characteristics, as well as impacts of environment in packaged software selection factors, different frameworks and procedure may be required in the software package selection process by SMEs' owners and managers when it comes to select packaged software in SMEs, in particular in different countries [14].

Nowadays, as Iranian SMEs awareness of the need to derive benefit from IT is growing, the majority of them continue to invest on IT to increase competitiveness. However, regarding this fact that Iranian SMEs are suffering from restricted financial, human and technical resources, they usually purchase packaged software to satisfy their business needs for IT. In addition most of Iranian SMEs are selecting and using domestically provided software package instead of worldwide distributed software. Due specific 
characteristics of Iranian SMEs such as differences on official definition of small and medium sized enterprise in Iran and unique economic structure, reasons affecting selection of packaged software by these businesses can be relatively different.

With regard to above mentioned views, this research investigates and present factors affecting selection of packaged software by Iranian SMEs to presents fitting methodology to suggest the most appropriate domestic packaged software for manufacturing SMEs in Iran.

\section{Factors used in the selection of Iranian packaged software:}

According to the literature, several factors were found to influence the selection of packaged software $[12,14,20,21,22]$. Through the review of literate, these factors are listed and defined in Table 1. These factors which affect the decision of CEOs of SMEs in selecting appropriate packaged software are attributable to the technical and nontechnical characteristics of packaged software, technical and non-technical specification of software provider and/or vendor and finally suggestion received from technical and nontechnical sources.

Table (1): Factor affecting the selection of packaged software

\begin{tabular}{|c|c|c|}
\hline $\begin{array}{l}\text { Criteria } \\
\text { aroup }\end{array}$ & Criteria & Definition \\
\hline \multirow{10}{*}{$\begin{array}{l}\text { Technical side } \\
\text { of software }\end{array}$} & Interoperability & $\begin{array}{l}\text { ability to be integrated with other tools and } \\
\text { applications and systems }\end{array}$ \\
\hline & $\begin{array}{l}\text { Compatibility (with } \\
\text { existing } \\
\text { hardware/software) }\end{array}$ & $\begin{array}{l}\text { Capability to satisfactorily perform through using } \\
\text { available hardware and software }\end{array}$ \\
\hline & $\begin{array}{l}\text { Ease of use/user- } \\
\text { friendliness }\end{array}$ & $\begin{array}{l}\text { Easiness and friendliness with which user could } \\
\text { learn and operate the packaged software }\end{array}$ \\
\hline & $\begin{array}{l}\text { Ease of } \\
\text { implementation }\end{array}$ & $\begin{array}{l}\text { The extent to which implementation of packaged } \\
\text { software in easy for both vendor and customer }\end{array}$ \\
\hline & Usability & $\begin{array}{l}\text { Capability of the software package to be used by } \\
\text { users having different skills in different industries } \\
\text { to solve dissimilar kinds of } \\
\text { business issues }\end{array}$ \\
\hline & $\begin{array}{l}\text { Availability of } \\
\text { source code and/or } \\
\text { required modules }\end{array}$ & $\begin{array}{l}\text { Availability of modules for being distributed on } \\
\text { different servers, as well as the availability of } \\
\text { source code which determines the } \\
\text { accessibility and modifiability of the component }\end{array}$ \\
\hline & $\begin{array}{l}\text { Fulfilling user } \\
\text { requirements }\end{array}$ & $\begin{array}{l}\text { The extent to which packaged software offer } \\
\text { features and interface required by users }\end{array}$ \\
\hline & Recoverability & $\begin{array}{l}\text { ability of the packaged software to provide } \\
\text { backup and recovery feature }\end{array}$ \\
\hline & Reliability & $\begin{array}{l}\text { Capability of system to perform its functions in } \\
\text { routine, hostile or unexpected circumstances and } \\
\text { run consistently without crashing }\end{array}$ \\
\hline & Security & $\begin{array}{l}\text { Security issues and policies offered by software } \\
\text { such as security against being hacked, user } \\
\text { identification, access levels and etc. }\end{array}$ \\
\hline
\end{tabular}




\begin{tabular}{|c|c|c|}
\hline & Maintainability & $\begin{array}{l}\text { Capability of system required to correct errors } \\
\text { and add enhancements to the original packaged } \\
\text { software such as number of users }\end{array}$ \\
\hline & $\begin{array}{l}\text { Required } \\
\text { experience and } \\
\text { skills }\end{array}$ & $\begin{array}{l}\text { The extent to which packaged software has } \\
\text { necessitated certain degree of skills and } \\
\text { experience for users }\end{array}$ \\
\hline & Integrity correctness & $\begin{array}{l}\text { Extent to which packaged software exactly } \\
\text { performs its tasks as defined by the requirements } \\
\text { and specifications }\end{array}$ \\
\hline & Flexibility & $\begin{array}{l}\text { Capability of system to personalize the layout of } \\
\text { package interface, as well as layout of reports } \\
\text { produced by package }\end{array}$ \\
\hline & Openness & $\begin{array}{l}\text { Level of openness to both further internal and } \\
\text { external development to other existing } \\
\text { applications }\end{array}$ \\
\hline & $\begin{array}{l}\text { Programming } \\
\text { languages }\end{array}$ & $\begin{array}{l}\text { The programming languages of packaged } \\
\text { software and ability of adjusting software and } \\
\text { personalizing modules using this language }\end{array}$ \\
\hline & visualization & $\begin{array}{l}\text { ability of the packaged software to creating and } \\
\text { present data effectively as images, diagrams, or } \\
\text { animations }\end{array}$ \\
\hline & Error reporting & $\begin{array}{l}\text { capability of the software package to report and } \\
\text { message errors within software functions and } \\
\text { data }\end{array}$ \\
\hline & $\begin{array}{l}\text { compatibility with } \\
\text { ISOs and } \\
\text { customer/suppliers } \\
\text { standards }\end{array}$ & $\begin{array}{l}\text { The extent to which the different features of } \\
\text { packaged software and its output (reports, data } \\
\text { management, documentation, diagrams and etc) } \\
\text { is able to satisfactorily fulfill different standards } \\
\text { (e.g. ISOs) requirements. }\end{array}$ \\
\hline & Direct benefits & $\begin{array}{l}\text { Benefits achieved by tangible savings in labor } \\
\text { and equipment, adding worth to product and } \\
\text { service, reduction in processing cost per unit and } \\
\text { elimination of outside service charges }\end{array}$ \\
\hline & Indirect benefits & $\begin{array}{l}\text { Benefits achieved through improvement in } \\
\text { customer service quality, improved data } \\
\text { management and faster turnaround time of } \\
\text { processing }\end{array}$ \\
\hline \multirow{3}{*}{$\begin{array}{l}\text { Non-technical } \\
\text { side of } \\
\text { software }\end{array}$} & Price & $\begin{array}{l}\text { Price of packaged software which includes costs } \\
\text { of licensing, training, installation and deployment, } \\
\text { required hardware, maintenance and upgrade }\end{array}$ \\
\hline & Popularity & Popularity of vendor in the market \\
\hline & Product availability & $\begin{array}{l}\text { The extended to which an product is available in } \\
\text { the market and easy to purchase }\end{array}$ \\
\hline \multirow{2}{*}{$\begin{array}{l}\text { Technical side } \\
\text { of } \\
\text { vendor/service } \\
\text { provider }\end{array}$} & $\begin{array}{l}\text { Availability of } \\
\text { Technical support } \\
\text { (warranty) }\end{array}$ & $\begin{array}{l}\text { high-quality upgrade service and deployment } \\
\text { experience, adequate technical resources, as } \\
\text { well as availability of consultancy and technical } \\
\text { support by the vendor }\end{array}$ \\
\hline & $\begin{array}{l}\text { Availability of user } \\
\text { training }\end{array}$ & $\begin{array}{l}\text { Availability of; user manual with important } \\
\text { information, tutorial to learn how to use the } \\
\text { software and training courses to learn the }\end{array}$ \\
\hline
\end{tabular}




\begin{tabular}{|c|c|c|}
\hline & & packaged software \\
\hline & Service response & $\begin{array}{l}\text { The time and level at which requested service is } \\
\text { rendered by vendor through phone or internet, as } \\
\text { well as by service agents }\end{array}$ \\
\hline & Vendor skills & $\begin{array}{l}\text { Technical and business skills of the vendor such } \\
\text { as high-quality upgrade service and } \\
\text { implementation experience or sufficient technical } \\
\text { resources }\end{array}$ \\
\hline & $\begin{array}{l}\text { Experience of using } \\
\text { products developed } \\
\text { by the same vendor }\end{array}$ & Past business experience with the vendor, if any \\
\hline \multirow{4}{*}{$\begin{array}{l}\text { Non-technical } \\
\text { side } \\
\text { vendor/service } \\
\text { provider }\end{array}$} & Free-trial version & $\begin{array}{l}\text { Availability of free-trial (demo) version and its } \\
\text { ability to represent quality of full version of } \\
\text { software }\end{array}$ \\
\hline & Reputation & $\begin{array}{l}\text { The extent at which vendor product is popular } \\
\text { and well-advertised in the market }\end{array}$ \\
\hline & References & $\begin{array}{l}\text { The extent to which utilization of the packaged } \\
\text { software has been referenced regarding existing } \\
\text { customers }\end{array}$ \\
\hline & Market share & $\begin{array}{l}\text { percentage of the market for a packaged } \\
\text { software that vendor supplies }\end{array}$ \\
\hline \multirow{3}{*}{$\begin{array}{l}\text { Suggestion } \\
\text { and opinion of } \\
\text { technical } \\
\text { sources }\end{array}$} & In-house experts & $\begin{array}{l}\text { Opinions given by in-house experts about the } \\
\text { importance, benefits and worth of certain } \\
\text { packaged software for business }\end{array}$ \\
\hline & External consultants & $\begin{array}{l}\text { Opinions given by external consultants about the } \\
\text { importance, benefits and worth of certain } \\
\text { packaged software for business }\end{array}$ \\
\hline & $\begin{array}{l}\text { Computer/IS trade } \\
\text { magazines, } \\
\text { software }\end{array}$ & $\begin{array}{l}\text { Opinions given by computer/IS trade magazines } \\
\text { about the importance, benefits and worth of } \\
\text { certain packaged software for business }\end{array}$ \\
\hline \multirow{3}{*}{$\begin{array}{l}\text { Suggestion } \\
\text { and opinion of } \\
\text { non-technical } \\
\text { sources }\end{array}$} & Subordinates & $\begin{array}{l}\text { Opinions given by subordinates about the } \\
\text { importance, benefits and worth of certain } \\
\text { packaged software for business }\end{array}$ \\
\hline & End-users & $\begin{array}{l}\text { Opinions given by end-users about the } \\
\text { importance, benefits and worth of certain } \\
\text { packaged software for business }\end{array}$ \\
\hline & $\begin{array}{l}\text { Outside personal } \\
\text { acquaintances }\end{array}$ & $\begin{array}{l}\text { Opinions given by outside personal } \\
\text { acquaintances about the importance, benefits } \\
\text { and worth of certain packaged software for } \\
\text { business }\end{array}$ \\
\hline
\end{tabular}

In the context of Iran SME sector, 12 packaged software described in Table 2 were found to cover the most demands of Iran's market for domestic packaged software, thus, these 12 packaged software have chosen as the 12 alternatives of this study. It should be considered that the packaged software having same code belongs to same vendors, but their feathers are different regarding their level of sophistication. For example, software A1 and $\mathrm{A} 2$ belongs to one producer, but, since their level of sophistication is different as shown in table 1 (A2 has one more feather than A1 which is named Production control, therefore, A2 is much more expensive), they are categorized as different packaged software. 
Table (2): Characteristics of domestic packaged software

\begin{tabular}{|c|c|c|c|c|c|c|c|c|}
\hline No & $\begin{array}{c}\text { Features } \\
\text { Softwake } \\
\text { package }\end{array}$ & $\begin{array}{c}\text { Account } \\
\text { ing }\end{array}$ & $\begin{array}{c}\text { Inventory } \\
\text { control } \\
\text { and } \\
\text { manage } \\
\text { ment }\end{array}$ & $\begin{array}{l}\text { Maintena } \\
\text { nce } \\
\text { manage } \\
\text { ment }\end{array}$ & $\begin{array}{c}\text { Producti } \\
\text { on } \\
\text { control }\end{array}$ & $\begin{array}{c}\text { Staff } \\
\text { inputlou } \\
\text { tput } \\
\text { control }\end{array}$ & Price & $\begin{array}{c}\text { Time of } \\
\text { Deploym } \\
\text { ent }\end{array}$ \\
\hline 1 & $\mathrm{~A}_{1}$ & $\checkmark$ & $\checkmark$ & & & $\checkmark$ & $565 \$$ & 10 days \\
\hline 2 & $\mathrm{~A}_{2}$ & $\checkmark$ & $\checkmark$ & & $\checkmark$ & $\checkmark$ & $785 \$$ & 14 days \\
\hline 3 & $\mathrm{~B}_{1}$ & $\checkmark$ & $\checkmark$ & & $\checkmark$ & & $640 \$$ & 20 days \\
\hline 4 & $\mathrm{~B}_{2}$ & $\checkmark$ & $\checkmark$ & & $\checkmark$ & $\checkmark$ & $730 \$$ & 20 days \\
\hline 5 & $\mathrm{C}_{1}$ & $\checkmark$ & $\checkmark$ & & & & $420 \$$ & 15 days \\
\hline 6 & $\mathrm{C}_{2}$ & $\checkmark$ & $\checkmark$ & & $\checkmark$ & & $690 \$$ & 25 days \\
\hline 7 & $\mathrm{C}_{3}$ & $\checkmark$ & $\checkmark$ & $\checkmark$ & $\checkmark$ & $\checkmark$ & $\begin{array}{c}1070 \\
\$\end{array}$ & 35 days \\
\hline 8 & $\mathrm{D}_{1}$ & & $\checkmark$ & & $\checkmark$ & & $680 \$$ & 25 days \\
\hline 9 & $\mathrm{D}_{2}$ & & $\checkmark$ & & $\checkmark$ & $\checkmark$ & $810 \$$ & 25 days \\
\hline 10 & $\mathrm{D}_{3}$ & & $\checkmark$ & $\checkmark$ & $\checkmark$ & $\checkmark$ & $\begin{array}{c}1150 \\
\$\end{array}$ & 30 days \\
\hline 1 & $\mathrm{E}_{1}$ & $\checkmark$ & $\checkmark$ & $\checkmark$ & $\checkmark$ & & $\begin{array}{c}1020 \\
\$\end{array}$ & 30 days \\
\hline 12 & $\mathrm{E}_{2}$ & $\checkmark$ & $\checkmark$ & $\checkmark$ & $\checkmark$ & $\checkmark$ & $\begin{array}{c}1250 \\
\$\end{array}$ & 30 days \\
\hline
\end{tabular}

\section{Research Methodology:}

This research investigates and presents factors affecting selection of packaged software by Iranian SMEs to provide fitting methodology by using Technique for Order Preference by Similarity to Ideal Solution (TOPSIS) to suggest the most appropriate domestic packaged software for Iranian manufacturing SMEs. The sampling frame of this research includes all manufacturing SMEs located in the main industrial areas of Semnan Province. The list of SMEs was obtained from the web site of the Semnan administration of industries and mines (http://www.imo-semnan.ir/). In this research, small enterprise is defined by a number of employees and it refers to enterprise with fewer than 50 employees while medium-sized enterprise refers to enterprise by the greatest extent of 250 annual work units.

As stated previously, IT adoption process in SMEs is directly affected by top management (Nguyen, 2009) where in most cases, owner and chief manager are one and the same person (Nie, 2007). Hence, only CEOs (owners or managers) of the manufacturing SMEs are targeted as the respondents of this research since they own or oversee the entire operations of their business and are responsible and decision maker for all stages of IT adoption. Therefore, using a questionnaire-based survey, 121 CEOs of SMEs were interviewed. This survey aims to reveal the perceived importance of factor listed in Table 1 , which affect the selection of packaged software. In addition a number of interviews with IT experts, vendors, producers of packaged software and software engineers were also performed to determine the status of each packaged-software regarding each criterion. These criteria includes both quantitative and qualitative. Using questions with five-point Likert answers, the answer of interviewed experts to qualitative questions range for example from very low to very high, very weak to very strong and etc. Within 32 
investigated criteria, price, time of implementation (days) and vendor's market share $(\mathrm{C} 1$, C2 and C3) in decision matrix (Table 3) are quantitative, as a result, all remaining 29 criteria in decision matrix are quantitative. Therefore, with the contribution of experts in this field (IT experts, vendors, producers of packaged software and software engineers), those had also contributed in the evaluation of each software package's 32 criteria, as well as by using spatial bipolar scale as one of the most appropriate method for qualitative to quantitative conversion, the values of these 29 qualitative criteria for each packaged software (alternative) were converted to quantitative values to form the decision matrix of this study shown in Table 3.

Within the previous literature, a number of approaches such as multi-criteria decision making analysis, mathematical optimization, scoring, ranking, and mathematical optimization have been applied with the aim of IT tools selection [6]. In this research a TOPSIS-based method is used to offer the order of most appropriate domestic packaged software in Iran offered to SMEs. The multiple criteria decision making (MCDM) method, TOPSIS, is based on an aggregating function representing "closeness to the ideal". The TOPSIS method determines a solution with the shortest distance to the ideal solution and the greatest distance from the negative-ideal solution, but it does not consider the relative importance of these distances [23]. The aim of TOPSIS is to find the closet solution to the ideal one since in the real world, access to the ideal answer and solution is almost impossible or inaccessible [24].

In TOPSIS method, it is hypothesized that;

- Each attribute (variable) in the decision matrix takes either monotonically increasing or monotonically decreasing utility;

- $\quad$ A set of weights for the attributes is required;

- $\quad$ Any outcome which is expressed in a non-numerical way should be quantified through the appropriate scaling technique. 
Table (3): Decision matrix

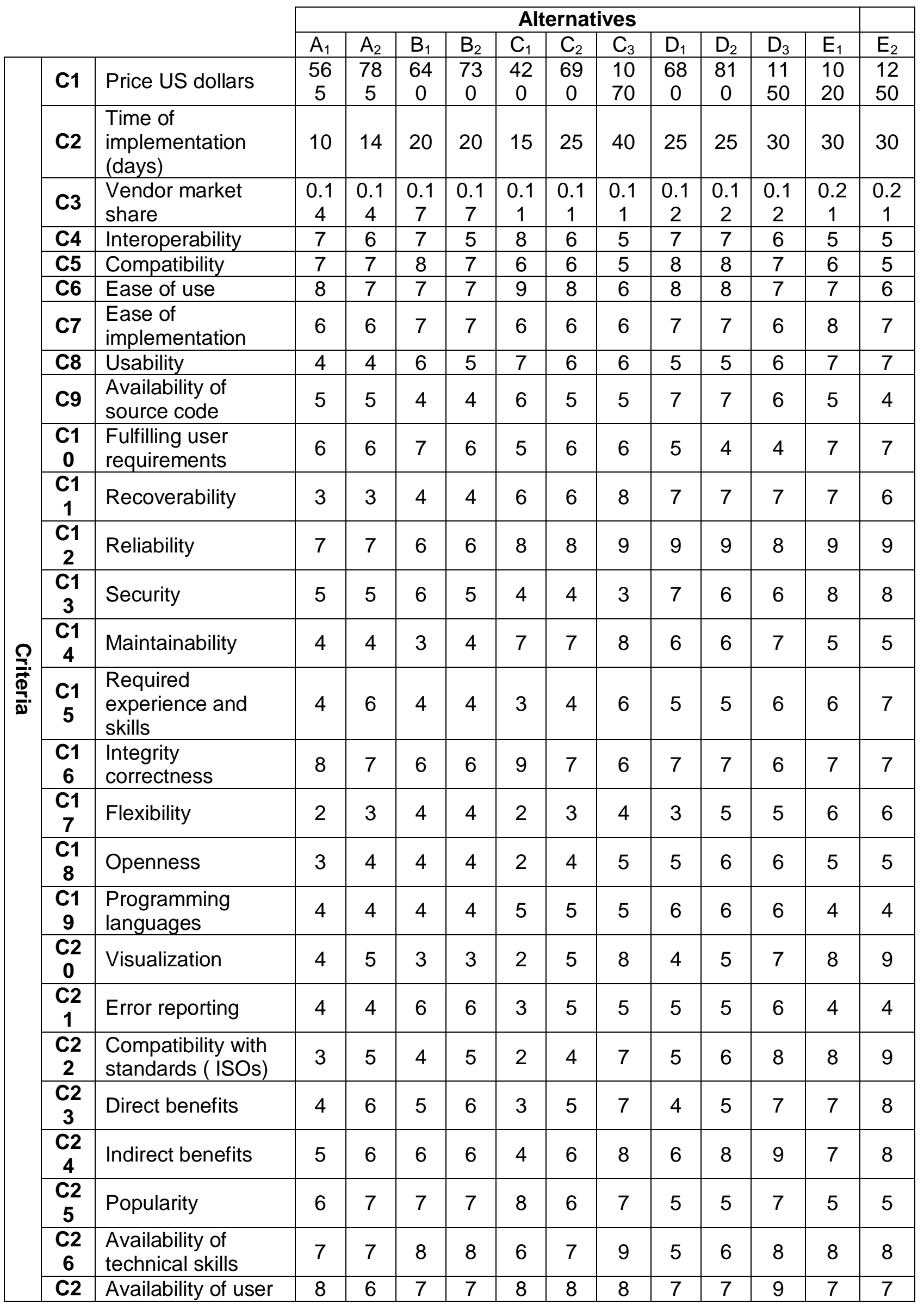




\begin{tabular}{|c|c|l|l|l|l|l|l|l|l|l|l|l|l|}
\hline $\mathbf{7}$ & training & & & & & & & & & & & & \\
\hline $\begin{array}{c}\text { C2 } \\
\mathbf{8}\end{array}$ & Service response & 6 & 6 & 5 & 5 & 6 & 6 & 4 & 4 & 4 & 5 & 7 & 7 \\
\hline $\begin{array}{c}\mathbf{C 2} \\
\mathbf{9}\end{array}$ & Vendor skills & 7 & 7 & 6 & 6 & 5 & 5 & 5 & 8 & 8 & 8 & 6 & 6 \\
\hline $\begin{array}{c}\mathbf{C 3} \\
\mathbf{0}\end{array}$ & Free-trial version & 1 & 1 & 5 & 5 & 4 & 4 & 4 & 1 & 1 & 1 & 6 & 6 \\
\hline $\begin{array}{c}\mathbf{C 3} \\
\mathbf{1}\end{array}$ & Reputation & 8 & 8 & 5 & 5 & 6 & 5 & 5 & 5 & 5 & 6 & 7 & 7 \\
\hline $\begin{array}{c}\mathbf{C 3} \\
\mathbf{2}\end{array}$ & References & 7 & 7 & 4 & 4 & 7 & 5 & 5 & 6 & 6 & 6 & 7 & 8 \\
\hline
\end{tabular}

\section{Using a TOPSIS-based approach to solve the problem:}

In this Research, using a TOPSIS-based approach, 12 alternatives are evaluated by 32 attributes (criteria). As a result, each problem can be defined as a numeral system which includes 12 point inside a 32-dimensional space; therefore, the chosen alternative solution should have the shortest distance from the positive ideal solution $\left(A_{i}^{+}\right)$and the farthest distance from the negative ideal solution $\left(A_{i}^{-}\right)$. After forming decision matrix (Table 3$)$, this approach is applied through six steps.

\subsection{Descaling by normalized decision matrix:}

Using formula (1), decision matrix has been transformed to the normalized decision matrix. The rationale behind is making these attributes (criteria) comparable, summable and subtractable. Thus, normalized decision matrix is calculated.

$$
r_{i j}=\frac{x_{i j}}{\sqrt{\sum_{i=1}^{m} x_{i j}^{2}}}
$$

$i=$ th row in decision matrix

$j=j$ th column in decision matrix

$r_{i j}=$ normalized $x_{i j}$

$x_{i j}=$ value $i j$ in decision matrix

\subsection{Weighted normalized decision matrix:}

In this step, the weighted normalized value $v_{\mathrm{ij}}$ is calculated as:

$v_{i j}=w_{i} r_{i j}, \quad j=1, \ldots, m ; i=1, \ldots, n$, where $w_{i}$ is the weight of the th attribute or criterion, and . $\quad \sum_{i=1}^{n} \bar{w}_{i}=1$ i problem, the Shannon entropy method is used. This method which is on the ivasis ur Iriformation uncertainly within a data set was originated from information theory and was introduced in 1948 by Shannon [25] to provide a quantitative measure of the "uncertainty" represented by a discrete probability distribution [26], which is based on three measures: entropy $\left(E_{j}\right)$, degree of divergence $\left(d_{j}\right)$, and degree of influence or weight of importance $\left(\mathrm{F}_{j}\right)[27,28]$.

$\mathbf{E j}$ (entropy value or degree of uncertainty) $=-\mathbf{K} \sum_{i=1}^{m}\left[\left[\mathbf{P i j}_{i}\right] \mathbf{L n P i j}\right]$

$\mathbf{K}=\frac{1}{\operatorname{Ln}(m)}$, were $m=$ number of attributes

$d_{j}($ degree of divergence $)=1-E_{j}$ 
$\mathrm{w}_{\mathbf{j}}$ (weights) $=\frac{d \mathrm{j}}{\sum_{i=1}^{n} d \mathrm{j}}$

$\mathbf{w}^{j}$ (modulated weights) $=\frac{\lambda j \cdot w j}{\sum_{i=1}^{n} \lambda j \cdot w j}$, where $F_{j}$ are the weights of importance

Here, it should be noted that in order to calculate weight of importance for each criteria, the data collected from 121 managers of SMEs have been used so that obtained Mean (in this study 5 point Likert scale has been used) for each criteria has been assumed as the weight of importance. Table 5 shows the calculated weight matrix using subjective values. Consequently, through multiplying weight matrix to normalized decision matrix, weighted normalized decision matrix has been resulted.

\subsection{Determination of the ideal and negative-ideal solution:}

After formulating the weighted normalized decision matrix, ideal and negative-ideal solutions are defined using following terms. TOPSIS method will rank order the alternatives based on their closeness to positive and negative ideal solutions [29], so that chosen alternative solutions should have the shortest distance from the positive ideal solution $\left(\mathrm{Ai}^{+}\right)$and the farthest distance from the negative ideal solution $\left(\mathrm{Ai}^{\mathrm{i}}\right)$.

$$
\begin{aligned}
& \begin{aligned}
A^{+} & =\left\{\left(\max _{i} v_{i j} \mid j \in J\right),\left(\min _{i} v_{i j} \mid j \in J\right) \mid i=1,2, \ldots m\right\} \\
& =\left\{v_{1}^{+}, v_{2}^{+}, \ldots, v_{j}^{+}, \ldots, v_{n}^{+}\right\}
\end{aligned} \\
& \begin{aligned}
A^{-}= & \left\{\left(\min _{i} v_{i j} \mid j \in J\right),\left(\max _{i} v_{i j} \mid j \in J\right) \mid i=1,2, \ldots m\right\} \\
= & \left\{v_{1}^{-}, v_{2}^{-}, \ldots, v_{j}^{-}, \ldots, v_{n}^{-}\right\}
\end{aligned} \\
& \text {where } \quad J=\{j=1,2, \ldots, n j \text { associated with benefit criteria }\} \\
& \quad J^{\prime}=\{j=1,2, \ldots, n j \text { associated with cost criteria }\}
\end{aligned}
$$

As a result, with regard to the above mentioned terms, ideal and negative-ideal solution (positive ideal solution $=A^{+}$, negative ideal solution $\left.=A^{-}\right)$for each of 32 criteria $\left(C_{1}, C_{2} \ldots\right.$ $\mathrm{C}_{32}$ ) will respectively be defined as:

$A^{+}=\{0.0072,0.0071,0.0094,0.0053,0.0047,0.0025,0.0016,0.0065,0.0046,0.0055$, $0.0165,0.0033,0.0155,0.0150,0.0047,0.0030,0.0217,0.0131,0.0031,0.0372,0.0058$, $0.0386,0.0165,0.009,0.0034,0.0052,0.0021,0.0064,0.0056,0.0772,0.0055,0.0078\}$ $A^{-}=\{0.0214,0.0281,0.0047,0.0033,0.0030,0.0017,0.0012,0.0037,0.0027,0.0031$, $0.0062,0.0022,0.0058,0.0056,0.0110,0.0020,0.0073,0.0044,0.0021,0.0083,0.0029$, $0.0086,0.0062,0.0044,0.0021,0.0029,0.0014,0.0036,0.0035,0.0129,0.0034,0.0039\}$

\subsection{Calculating the separation measures, using the $\mathbf{N}$ dimensional Euclidean distance:}

$\begin{array}{ll}\text { Positive-ideal separation: } & S_{i}^{+}=\sqrt{\sum_{j=1}^{n}\left(v_{i j}-v_{j}^{+}\right)^{2}} \quad i=1,2, \ldots, m \\ \text { Negative-ideal separation: } & S_{i}^{-}=\sqrt{\sum_{j=1}^{n}\left(v_{i j}-v_{j}^{-}\right)^{2}} \quad i=1,2, \ldots, m\end{array}$ 
Table (5): weight matrix

\begin{tabular}{|c|c|c|c|c|c|c|}
\hline & & & Wj & $\lambda$ & $\mathbf{W j}^{*} \boldsymbol{\lambda}$ & $W^{\prime} \mathbf{j}$ \\
\hline & C1 & Price US dollars & 0.042 & $\begin{array}{c}4.18 \\
4\end{array}$ & 0.175 & 0.051 \\
\hline & C2 & Time of implementation (days) & 0.057 & $\begin{array}{c}3.69 \\
1 \\
\end{array}$ & 0.210 & 0.061 \\
\hline & C3 & Vendor market share & 0.031 & $\begin{array}{c}2.58 \\
8\end{array}$ & 0.079 & 0.023 \\
\hline & C4 & Interoperability & 0.012 & $\begin{array}{c}4.02 \\
2\end{array}$ & 0.049 & 0.014 \\
\hline & C5 & Compatibility & 0.012 & $\begin{array}{c}4.11 \\
8\end{array}$ & 0.048 & 0.014 \\
\hline & C6 & Ease of use & 0.006 & $\begin{array}{c}3.80 \\
1\end{array}$ & 0.024 & 0.007 \\
\hline & C7 & Ease of implementation & 0.004 & $\begin{array}{c}3.58 \\
8 \\
\end{array}$ & 0.016 & 0.005 \\
\hline & C8 & Usability & 0.016 & $\begin{array}{c}3.97 \\
8\end{array}$ & 0.064 & 0.019 \\
\hline & C9 & Availability of source code & 0.017 & $\begin{array}{c}2.44 \\
1 \\
\end{array}$ & 0.043 & 0.012 \\
\hline & C10 & Fulfilling user requirements & 0.015 & $\begin{array}{c}3.56 \\
6 \\
\end{array}$ & 0.055 & 0.016 \\
\hline & C11 & Recoverability & 0.044 & $\begin{array}{c}3.34 \\
6 \\
\end{array}$ & 0.146 & 0.042 \\
\hline$\stackrel{\Upsilon}{\fallingdotseq}$ & C12 & Reliability & 0.010 & $\begin{array}{c}3.64 \\
0\end{array}$ & 0.036 & 0.010 \\
\hline$\frac{\underline{0}}{\mathrm{~d}}$ & C13 & Security & 0.035 & $\begin{array}{c}3.83 \\
8\end{array}$ & 0.134 & 0.039 \\
\hline & C14 & Maintainability & 0.036 & $\begin{array}{c}3.51 \\
5 \\
\end{array}$ & 0.128 & 0.037 \\
\hline & C15 & Required experience and skills & 0.026 & $\begin{array}{c}3.71 \\
3\end{array}$ & 0.096 & 0.028 \\
\hline & C16 & Integrity correctness & 0.007 & $\begin{array}{c}3.85 \\
3 \\
\end{array}$ & 0.028 & 0.008 \\
\hline & C17 & Flexibility & 0.055 & $\begin{array}{c}3.22 \\
8\end{array}$ & 0.179 & 0.052 \\
\hline & C18 & Openness & 0.033 & $\begin{array}{c}3.62 \\
5 \\
\end{array}$ & 0.120 & 0.035 \\
\hline & C19 & Programming languages & 0.014 & $\begin{array}{c}2.08 \\
8\end{array}$ & 0.030 & 0.009 \\
\hline & C20 & Visualization & 0.082 & $\begin{array}{c}3.41 \\
9 \\
\end{array}$ & 0.281 & 0.081 \\
\hline & C21 & Error reporting & 0.019 & $\begin{array}{c}3.02 \\
2 \\
\end{array}$ & 0.056 & 0.016 \\
\hline & C22 & Compatibility with standards (ISOs) & 0.070 & $\begin{array}{c}4.32 \\
4 \\
\end{array}$ & 0.302 & 0.087 \\
\hline & C23 & Direct benefits & 0.033 & $\begin{array}{c}4.31 \\
6 \\
\end{array}$ & 0.142 & 0.041 \\
\hline & C24 & Indirect benefits & 0.021 & $\begin{array}{c}4.10 \\
3\end{array}$ & 0.088 & 0.025 \\
\hline
\end{tabular}




\begin{tabular}{|l|l|l|c|c|c|c|}
\hline $\mathbf{C 2 5}$ & Popularity & 0.013 & $\begin{array}{c}2.53 \\
7\end{array}$ & 0.032 & 0.009 \\
\hline C26 & Availability of technical skills & 0.011 & $\begin{array}{c}4.53 \\
7\end{array}$ & 0.051 & 0.015 \\
\hline C27 & Availability of user training & 0.005 & $\begin{array}{c}4.14 \\
7\end{array}$ & 0.021 & 0.006 \\
\hline $\mathbf{C 2 8}$ & Service response & 0.018 & $\begin{array}{c}3.38 \\
2\end{array}$ & 0.060 & 0.017 \\
\hline $\mathbf{C 2 9}$ & Vendor skills & 0.014 & $\begin{array}{c}3.79 \\
4\end{array}$ & 0.055 & 0.016 \\
\hline C30 & Free-trial version & 0.203 & $\begin{array}{c}2.89 \\
7\end{array}$ & 0.587 & 0.170 \\
\hline $\mathbf{C 3 1}$ & Reputation & 0.017 & $\begin{array}{c}2.94 \\
1\end{array}$ & 0.050 & 0.015 \\
\hline $\mathbf{C 3 2}$ & References & 0.021 & $\begin{array}{c}3.44 \\
9\end{array}$ & 0.071 & 0.021 \\
\hline
\end{tabular}

At the next step, by using equation 9 and 10, positive-ideal and negative-ideal separation measures are calculated and shown in Table 6:

\subsection{Calculating the relative closeness to the ideal solution:}

Using following formula, relative closeness to the ideal solution for each alternative have been calculated and shown in Table 7 .

Relative closeness of $i$ th alternative to the ideal solution:

$\boldsymbol{C}_{i}^{*}=\frac{\boldsymbol{S}_{i}^{-}}{\left(\boldsymbol{S}_{i}^{+}+\boldsymbol{S}_{i}^{-}\right)}, \quad 0<\boldsymbol{C}_{i}^{*}<1, \quad i=1,2, \ldots, m$

Table (6): Positive-ideal and negative-ideal separation

\begin{tabular}{|c|c|c|c|}
\hline $\begin{array}{c}\text { Type of Packaged } \\
\text { Software }\end{array}$ & $\begin{array}{c}\text { Alternative } \\
\text { No. }\end{array}$ & $\begin{array}{c}\text { Negative-ideal } \\
\text { separation }\end{array}$ & $\begin{array}{c}\text { Positive-ideal } \\
\text { separation }\end{array}$ \\
\hline$A_{1}$ & $A 1$ & 0.027321603 & 0.076160423 \\
\hline$A_{2}$ & $A 2$ & 0.028985169 & 0.071825344 \\
\hline$B_{1}$ & $A 3$ & 0.056797535 & 0.040405198 \\
\hline$B_{2}$ & $A 4$ & 0.057322421 & 0.038120073 \\
\hline$C_{1}$ & $A 5$ & 0.046433824 & 0.054424811 \\
\hline$C_{2}$ & $A 6$ & 0.04580262 & 0.043003721 \\
\hline$C_{3}$ & $A 7$ & 0.054401676 & 0.039527287 \\
\hline$D_{1}$ & $A 8$ & 0.026501698 & 0.072549845 \\
\hline$D_{2}$ & $A 9$ & 0.031855926 & 0.069768904 \\
\hline$D_{3}$ & $A 10$ & 0.040228224 & 0.068340983 \\
\hline$E_{1}$ & $A 11$ & 0.077742074 & 0.020610434 \\
\hline$E_{2}$ & $A 12$ & 0.080669883 & 0.022630731 \\
\hline
\end{tabular}


Table (7): Relative closeness to the ideal solution for each alternative

\begin{tabular}{|c|c|c|}
\hline $\begin{array}{c}\text { Type of Packaged } \\
\text { Software }\end{array}$ & Alternative No. & Relative closeness \\
\hline$A_{1}$ & $\mathrm{~A} 1$ & 0.264023 \\
\hline $\mathrm{A}_{2}$ & $\mathrm{~A} 2$ & 0.287521 \\
\hline $\mathrm{B}_{1}$ & $\mathrm{~A} 3$ & 0.58432 \\
\hline $\mathrm{B}_{2}$ & $\mathrm{~A} 4$ & 0.600596 \\
\hline $\mathrm{C}_{1}$ & $\mathrm{~A} 5$ & 0.460385 \\
\hline $\mathrm{C}_{2}$ & $\mathrm{~A} 6$ & 0.515758 \\
\hline $\mathrm{C}_{3}$ & $\mathrm{~A} 7$ & 0.579179 \\
\hline $\mathrm{D}_{1}$ & $\mathrm{~A} 8$ & 0.267555 \\
\hline $\mathrm{D}_{2}$ & $\mathrm{~A} 9$ & 0.313466 \\
\hline $\mathrm{D}_{3}$ & $\mathrm{~A} 10$ & 0.370531 \\
\hline $\mathrm{E}_{1}$ & $\mathrm{~A} 11$ & 0.790443 \\
\hline $\mathrm{E}_{2}$ & $\mathrm{~A} 12$ & 0.780924 \\
\hline
\end{tabular}

\subsection{Ranking the preference order:}

Finally, a set of alternatives can now be ranked in preference order according to the descending order of $C_{i}^{*}$. In other word, alternatives (packaged software) having greater value $C^{*}$ will be the best choice respectively. Therefore, in this research, the order of best fit packaged software for Iranian SMEs will be as; $E_{1}, E_{2}, B_{2}, B_{1}, C_{3}, C_{2}, C_{1}, D_{3}, D_{2}, A_{2}, D_{1}, A_{1}$

\section{Conclusions:}

This paper presents the TOPSIS-based approach to determine the fittest domestic packaged software with requirements of Iranian manufacturing SMEs. In order to determine the perceived importance of factors affecting the selection of packaged software, 121 CEO of manufacturing SMEs were interviewed through personal administrative questionnaire. In addition, in order to determine the status of 12 packaged software (available for Iranian SMEs) regarding each investigated factor affecting selection process, several interview with experts such as producers of packaged software and software engineers were also performed. The provided order of fittest domestic packaged available for manufacturing SMEs in Iran may help decision makers to select the most appropriate packaged software to fit with business.

\section{References:}

[1]. S. Pavic, S. C. L. Koh, M. Simpson and J. Padmore, Could E-Business Create a Competitive Advantage in UK SMEs?, Benchmarking Vol. 14, No. 3, P. 320-351, 2007.

[2]. F. Lai, X. Zhao and Q. Wang, The Impact of Information Technology on the Competitive Advantage of Logistics Firms in China, Industrial Management \& Data Systems Vol. 106, No. 9, P. 1249-1271,2006.

[3]. T. U. H. Nguyen, Information Technology Adoption in SMEs: An Integrated Framework, International Journal of Entrepreneurial Behaviour \& Research, Vol. 15, No. 2, P. 162-186, 2009.

[4]. I. Shin, Adoption of Enterprise Application Software and Firm Performance, Small Business Economics, Vol. 26, No. 3, p. 241-256, 2006. 
[5]. M. Corso, A. Martini, L. Pellegrini and E. Paolucci, Technological and Organizational Tools for Knowledge Management: In search of Configurations, Small Business Economics, Vol. 21, No. 4, p. 397-408, 2003.

[6]. C. C. Wei, C. F. Chien and M. J. J. Wang, An AHP-based Approach to ERP System Selection, International Journal of Production Economics, Vol. 96, No. 1, P. 47-62, 2005.

[7]. M. Levy, P. Powell and P. Yetton, Smes: Aligning IS and the Strategic Context, Journal of Information Technology, Vol. 16, No. 3, P. 133-144, 2001.

[8]. P. E. D. Love, Z. Irani, C. Standing, C. Lin and J. M. Burn, The Enigma of Evaluation: Benefits, Costs and Risks of IT in Australian Small-Medium-Sized Enterprises, Information \& Management, Vol. 42, No. 7, P. 947-964, 2005.

[9]. J. Y. L. Thong and C. S. Yap, CEO Characteristics, Organizational Characteristics and Information Technology Adoption in Small Businesses, Omega, Vol. 23, No. 4, P. 429-442, 1995.

[10]. K. F. Mole, A. Ghobadian, N. O'Regan and J. Liu, The Use and Deployment of Soft Process Technologies Within UK Manufacturing SMEs: An Empirical Assessment Using Logit Models, Journal of Small Business Management, Vol. 42, No. 3, P. 303-324, 2004.

[11]. D. Howcroft and B. Light, A Study of User Involvement in Packaged Software Selection, Proceeding of the 23rd International Conference on Information Systems, P. 69-77, 2002.

[12]. D. Howcroft and B. Light,, Reflections on Issues of Power in Packaged Software Selection, Information Systems Journal, Vol. 16, No. 3, P. 215-235, 2006.

[13]. A. Azadeh, S. N. Shirkouhi and K. Rezaie, A Robust Decision-Making Methodology for Evaluation and Selection of Simulation Software Package, International Journal of Advanced Manufacturing Technology, Article in Press, P. 1-13, 2009.

[14]. P. Y. K. Chau, Factors Used in the Selection of Packaged Software in Small Businesses: Views of Owners and Managers, Information \& Management, Vol. 29, No. 2, P. 71-78, 1995.

[15]. B. Light, CRM Packaged Software: A Study of Organisational Experiences, Business Process Management Journal, Vol. 9, No. 5, P. 603-616, 2003.

[16]. I. P. Tatsiopoulos and N. D. Mekras, An Expert System for the Selection of Production Planning and Control Software Packages, Production Planning \& Control: The Management of Operations, Vol. 10, No. 5, P. 414 - 425. 1999.

[17]. J. Nie, A Study of Information Technology Adoption for Small and Medium Sized Enterprises Strategic Competitiveness, 2007 International Conference on Wireless Communications, Networking and Mobile Computing, WiCOM 2007, P. 4337-4341, 2007.

[18]. N. Fuller-Love, Management Development in Small Firms, International Journal of Management Reviews, Vol. 8, No. 3, pp. 175-190, 2006.

[19]. M. Smith, "Real" Managerial Differences Between Family and Non-family Firms, International Journal of Entrepreneurial Behaviour and Research, Vol. 13, No. 5, P. 278-295, 2007.

[20]. X. Franch and J. P. Carvallo, Using Quality Models in Software Package Selection, IEEE software, Vol. 20, No. 1, P. 34-41, 2003.

[21]. A. R. Montazemi, D. A. Cameron and K. M. Gupta, An Empirical Study of Factors Affecting Software Package Selection, Journal of Management Information Systems, Vol. 13, No. 1, P. 89-105, 1996.

[22]. A. S. Jadhav and R. M. Sonar, Evaluating and Selecting Software Packages: A Review, Information and Software Technology, Vol. 51, No. 3, P. 555-563, 2009.

[23]. Y. J. Lai, T. Y. Liu and C. L. Hwang, TOPSIS for MODM, European Journal of 
Operational Research, Vol. 76, No. 3, P. 486-500, 1994.

[24]. C. T. Chen, Extensions of the TOPSIS for Group Decision-Making Under Fuzzy Environment, Fuzzy Sets and Systems, Vol. 114, No. 1, P. 1-9, 2000.

[25]. Shannon, E., \& Weaver, W. (1948). A mathematical theory of communication. Bell Syst. Tech. J, 27, 379-423.

[26]. Soo, H., Collura, J., Hobeika, A., \& Teodorovic, D. (2004). An Analytical Framework for Evaluating the Impacts of Advanced Traffic Signal Control Systems for Emergency Vehicle Preemption and Transit Priority. Paper presented at the ITS America's 14th Annual Meeting and Exhibition.

[27]. Hwang, C. L., \& Yoon, K. (1981). Multiple attribute decision making; methods and applications: a state-of-the-art survey. New York: Springer Verlag.

[28]. Yeh, C. H., \& Willis, R. J. (2001). A validation procedure for multi criteria analysis application to the selection of scholarship students. Asia Pacific Management Review, 6, 39-52.

[29]. Triantaphyllou, E., \& Lin, C. T. (1996). Development and evaluation of five fuzzy multiattribute decision-making methods. International Journal of Approximate Reasoning, 14(4), 281-310. 